\title{
Proximate Composition and Fatty Acids Profile in Oleaginous Seeds
}

\author{
Angela Claudia Rodrigues ${ }^{1}$, Aloísio Henrique Pereira de Souza ${ }^{2}$, Makoto Matsushita ${ }^{2}$, Lucia Felicidade Dias ${ }^{3}$, \\ Jesui Vergílio Visentainer ${ }^{2}$, Shawany Maldonado Tonsig ${ }^{3} \&$ Nilson Evelazio de Souza ${ }^{3}$ \\ ${ }^{1}$ Federal Technologic University of Parana, Department of Chemistry, Medianeira-PR, Brazil \\ ${ }^{2}$ State University of Maringa, Department of Chemistry, Maringá-PR, Brazil \\ ${ }^{3}$ Federal Technologic University of Parana, Department of Food Technology, Londrina-PR, Brazil \\ Correspondence: Nilson Evelazio de Souza, Federal Technologic University of Parana, Department of Food \\ Technology, Av. Dos Pioneiros, 3131, Jardim dos Pioneiros, CEP 86036-370, Londrina-PR, Brazil. E-mail: \\ nesouza@utfpr.edu.br
}

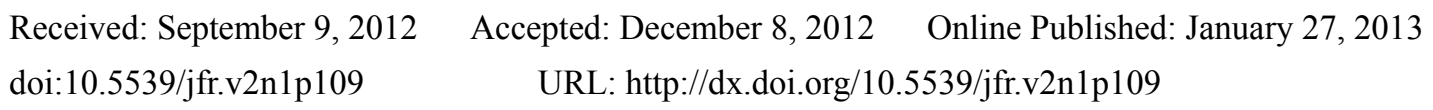

\begin{abstract}
Fatty acids were quantified in oleaginous seeds: pistachio, almonds, European nuts, cashew nuts, hazelnuts, Brazil nuts, pecan nuts, and macadamia nuts. Three brands of each sample were purchased in three lots $(\mathrm{n}=9)$. The proximate composition, energetic value, and fatty acids (FA) were determined by gas chromatography. All seeds had large amounts of total lipids and the highest contents (ca. 70\%) were found in macadamia, pecan, and European nuts. The samples had significant amounts of crude protein. Pistachio and cashew nuts had the greatest amount (ca. 20\%), as well as the largest carbohydrate contents (32\%). All seeds were rather energetic, ranging from 600 to $760 \mathrm{Kcal}^{-1}{ }^{-1}$. From seven to nine FA were identified and quantified, oleic (n-9) and linoleic (n-6) acids were the major acids. Essential fatty acid $\alpha$-linolenic (n-3) was found in European nuts (except pistachio) with an n-6/n-3 ratio (4:1) that is very beneficial to health. Trans FA were also observed in salted roasted cashew nuts. The major saturated FA (SFA) was palmitic, stearic, and arachidonic acids, however, their amounts were much lower than those of polyunsaturated acids (PUFA) and monounsaturated acids (MUFA). European nuts had the greatest PUFA/SFA ratio (9), followed by almonds (3.6).
\end{abstract}

Keywords: oleaginous seeds, nuts, proximate composition, fatty acids

\section{Introduction}

Oleaginous seeds are edible seeds that have low water contents and high oil or starch contents involved in a hard shell. Seeds in this category include nuts, almonds, Brazil nuts, hazelnuts, pistachio, and others.

These tree seeds contain vegetable protein, unsaturated fatty acids, fibers, vegetable steroids, and phytochemical micronutrients, such as tocopherols (Kornsteiner, Wagner, \& Elmadfa, 2006).

Oleaginous seeds have been part of human diet since pre-historical times and are considered the first foods consumed by human beings, together with fruit (Salas-Salvado, Casas-Agustench, \& Salas-Huetos, 2011). Fruit remains have been found in archeological sites dating back to 10,000 B. C. (Ritter \& Savage, 2007).

Therefore, oleaginous seeds have been important since pre-history due to their nutritional properties. Currently, oleaginous seeds are worldwide accepted because of their sensory and nutritional attributes (Sathe, 1994). Vegetarians value nuts (Ritter \& Savage, 2007) and consider them an alternative source of protein (Jun, 2009; Naozuka, Vieira, Nascimento, \& Oliveira, 2011; Yada, Lapsley, \& Huang, 2011; Alexiadou \& Katsilambros, 2011). The protein contents of nuts range from 20 to $25 \%(\mathrm{~m} / \mathrm{m})$ (Sathe, 1994).

Hard-shell edible seeds are known for their nutritional value and as valuable sources of lipids.The amounts of lipids vary from 45 to 70\% (Sathe, 1994; Alexiadou \& Katsilambros, 2011). Cashew nuts and pistachio have about $46 \%$, and macadamia nuts, $76 \%$ (Alexiadou \& Katsilambros, 2011). Therefore, they are foods rich in energy (Sathe, 1994; Alexiadou \& Katsilambros, 2011) and may provide 20-30 kJ.g ${ }^{-1}$ of oleaginous seeds (Alexiadou \& Katsilambros, 2011).

Despite their high lipid contents, they are not harmful to health because they have low amounts of SFA (4-16\%). They contain mostly unsaturated FA (Jun, 2009; Naozuka, Vieira, Nascimento, \& Oliveira, 2011; Yada, Lapsley, \& Huang, 2011; Alexiadou \& Katsilambros, 2011; Yang, Liu, \& Halim, 2009; Esfahlan, Jamei, \& Esfahlan, 
2010), monounsaturated FA (oleic acid, n-9), and polyunsaturated FA (linoleic fatty acid, n-6, and $\alpha$-linolenic acid, n-3) (Naozuka, Vieira, Nascimento, \& Oliveira, 2011; Alexiadou \& Katsilambros, 2011).

Studies indicate that the regular consumption of oleaginous seeds is associated with a reduced risk of fatal ischemia, cardiac diseases, and type-2 diabetes (Ritter \& Savage, 2007; Jun, 2009; Yada, Lapsley \& Huang, 2011; Alexiadou \& Katsilambros, 2011; Yang, Liu, \& Halim, 2009; Esfahlan, Jamei, \& Esfahlan, 2010). Another study also indicates that the substitution of half of the daily intake of lipids from other foods with lipids from seeds decreases the levels of total cholesterol and LDL in human beings significantly (Esfahlan, Jamei, \& Esfahlan, 2010).

Over 80,000 women who ate oleaginous seeds five times a week had the risk of cardiac disease reduced by $35 \%$ and of type-2 diabetes by $27 \%$. Additionally, individuals who ate nuts tended to weigh less. A study carried out in 10 European countries showed that women who ate $6.2 \mathrm{~g}$ of oleaginous seeds a day had the risk of colon cancer reduced by $31 \%$. According to Yang, Liu and Halim (2009), eating oleaginous seeds reduces the risk of cardiac diseases, which can be partially explained by the effect of the reduction in cholesterol.

Composition data are also essential for nutrition researchers, health professionals, and for food labeling (Yada, Lapsley, \& Huang, 2011). Given the nutritional importance of oleaginous seeds and the different nutritional compositions of these seeds due to environmental conditions and the species traits, the characterization of their nutrients is of great relevance. This study reports on the investigation of the nutritional composition of seed oils consumed by the Brazilian population.

\section{Materials and Methods}

\subsection{Sampling}

Samples of macadamia nuts (Macadamia integrifolia), pecan nuts (Caryaillinoensis K.), European nuts (Juglansregia L.), raw pistachio (Pistaciavera L.), salted roasted pistachio (SR), hazelnuts (Corylusavellana), raw almonds (R) (Prunusdulcis), salted roasted almonds (SR), Brazil nuts (Bertholletiaexcelsa), raw cashew nuts (R) (Anacardiumoccidentale L.), salted roasted cashew nuts (SR) purchased from local stores were analyzed.Three brands of each seed and three lots of each brand were analyzed in triplicate.

The samples were grounded in a food processor until they were homogeneous, vacuum packed, wrapped in aluminum foil and frozen stored until analysis.

\subsection{Chemical Analysis}

The moisture and ash contents were determined following Association of Official Analytical Chemists (Cunniff, 1998) and the crude protein content, by the Kjeldahl method (Instituto Adolfo Lutz, 2005).

The total lipids were extracted according to Bligh and Dyer (1959), and the total lipid contents were determined by gravimetry.

The carbohydrate content was calculated by difference: $100-(\%$ moisture $+\%$ ashes $+\%$ crude protein $+\%$ total lipids). The energy content in $\mathrm{Cal}(1 \mathrm{Cal}=1.000 \mathrm{cal}=1 \mathrm{Kcal})$ of the samples was calculated as the sum of percent crude protein and total carbohydrates times factor $4\left(\mathrm{Cal} . \mathrm{g}^{-1}\right)$ added to the total lipid content times factor $9\left(\mathrm{Cal}_{\mathrm{g}}{ }^{-1}\right)$, that is, the energetic value, $\mathrm{Cal}=[(4 \mathrm{x}$ protein content $)+(4 \mathrm{x}$ carbohydrate content $)+(9 \mathrm{x}$ total fat content)] (Holands, 1994).

\subsection{Fatty Acids Analysis}

Fatty acid methyl esters (FAME) were prepared as described by Hartman and Lago (1973) and adapted by Maia and Rodriguez-Amaya (1993). The esters were stored at $-18^{\circ} \mathrm{C}$ for later analysis.

FAME were separated by gas chromatography in CP-3380 (Varian, USA) fitted with Star software, a flame ionization detector, and a fused silica capillary column CP-7420 $(100 \mathrm{~m}, 0.25 \mathrm{~mm}$ and $0.39 \mu \mathrm{m}$ i.d. $100 \%$ bound cyanopropyl, Varian, USA). Chromatographic analysis conditions were: Carrier gas flow rate of $1.4 \mathrm{ml} . \mathrm{min}^{-1}$ $\left(\mathrm{H}_{2}\right)$, Auxiliary gas flow of $30 \mathrm{~mL} \cdot \mathrm{min}^{-1}\left(\mathrm{~N}_{2}\right)$, and 30 and $300 \mathrm{~mL} \cdot \mathrm{min}^{-1}$ of $\mathrm{H}_{2}$ and flame synthetic air, respectively. The split ratio used was $1 / 80$. Injections were made in triplicate in volumes of $2.0 \mu \mathrm{L}$. FA were identified by comparison with retention times of standard FAME containing geometric isomers of linoleic and $\alpha$-linolenic acids (Sigma FAME).

Methyl tricosanoate (23:0), $1.0 \mathrm{mg} \cdot \mathrm{mL}^{-1}$ in isooctane was used as an internal standard in quantifications. The internal standard was added to the esterification tube and the solvent was evaporated under nitrogen flow. The sample was weighed in the same tube. The FA identified in the samples were determined in mg.g ${ }^{-1}$ of sample using Equation 1 (Visentainer, 2006): 


$$
M_{x}=\frac{A_{X} \cdot M p \cdot F_{C T}}{A_{P} \cdot M_{A} \cdot F_{C E A}}
$$

where:

$\mathrm{M}_{\mathrm{x}}=$ Mass of fatty acid X in $\mathrm{mg} / \mathrm{g}$ of sample.

$\mathrm{M}_{\mathrm{P}}=$ Mass of internal standard in $\mathrm{mg}$.

$\mathrm{M}_{\mathrm{A}}=$ Mass of sample in $\mathrm{g}$.

$\mathrm{A}_{\mathrm{X}}=$ Area of fatty acid $\mathrm{X}$.

$\mathrm{A}_{\mathrm{P}}=$ Area of the internal standard.

$\mathrm{F}_{\mathrm{CT}}=$ Theoretical correction factor.

$\mathrm{F}_{\mathrm{CEA}}=$ Factor of conversion of methyl esters into fatty acids

\subsection{Statistical Analysis}

The mean fatty acid values were statistically analyzed using ANOVA and comparisons completed using Tukey's test. Significance at 5\% was used to establish differences. Data were processed using the Statistica 5.0 Software (Statistica, 2005).

\section{Results and Discussion}

The results (\%) of moisture, crude protein, ash, total lipid, calorie, and carbohydrate contents were obtained from the means of values of three brands of the same seed are given in Table 1.

The analysis of the results shows a significant variation between some samples. All samples had low moisture percent values, between 1.26 (European nuts) and 3.85\% (R cashew nuts). The ash results ranged from 1.25 to $4.76 \%$ for pecan nuts and SR pistachio.

The samples of European nuts, pecan, and macadamia nuts had the lowest and statistically equal amounts of crude proteins (12.37, 9.13 and $10.40 \%$, respectively). SR almonds, R cashew nuts, and SR cashew nuts presented crude protein contents in the range of 18.05 to $19.10 \%$, which were statistically equal to each other and to those of $\mathrm{R}$ almonds and Brazil nuts. SR pistachio and $\mathrm{R}$ pistachio had the largest and statistically equal contents of crude protein (20.26 and $20.54 \%$, respectively), which were also equal to those of R almonds, SR almonds, R cashew nuts and SR cashew nuts. Therefore, the consumer interested in buying seeds with higher protein content is advised to buy pistachio, almonds, and cashew nuts.

All samples had large amounts of total lipids with significant differences among some. The greatest amounts of total lipids were found in macadamia nuts (71.76\%), pecan nuts (68.81\%), Brazil nuts $(65.21 \%)$, and European nuts $(65.05 \%)$; all other samples were statistically equal. Hazelnuts, R almonds, SR almonds also were significantly equal, forming the group with the second greater value of total lipids $(55.75,53.58$ and $52.70 \%$, respectively).

$\mathrm{R}$ pistachio samples had $46.83 \%$ total lipids and were equal $(\mathrm{p}<5 \%)$ to $\mathrm{R}$ almonds and SR almonds. SR pistachio samples had $45.97 \%$ total lipids and were equal $(\mathrm{p}<5 \%$ ) to R pistachio and SR almonds. The lowest amounts of total lipids were found in R cashew nuts and 
Table 1. Mean contents (\%) of moisture, ashes, crude protein, total lipids, carbohydrates, and energy (calories in $\mathrm{kcal} / 100 \mathrm{~g}$ ) in the different seed brands

\begin{tabular}{|c|c|c|c|c|c|c|}
\hline Sample & Moisture & Ash & Crude protein & Total lipids & Carbohydrates** & Calories*** \\
\hline SR pistachio* & $2.56 \pm 0.357^{\mathrm{abc}}$ & $4.76 \pm 1.047^{\mathrm{a}}$ & $20.26 \pm 0.595^{\mathrm{a}}$ & $45.97 \pm 1.351^{\mathrm{de}}$ & $26.45 \pm 0.780$ & $600.6 \pm 12.12$ \\
\hline R pistachio* & $2.96 \pm 0.092^{\mathrm{ab}}$ & $2.95 \pm 0.021^{b c}$ & $20.54 \pm 0.523^{\mathrm{a}}$ & $46.83 \pm 0.502^{\text {cde }}$ & $26.72 \pm 1.105$ & $610.5 \pm 2.19$ \\
\hline European nuts & $1.26 \pm 0.141^{\mathrm{c}}$ & $1.60 \pm 0.087^{\mathrm{def}}$ & $12.37 \pm 0.681^{\mathrm{def}}$ & $65.05 \pm 2.766^{\mathrm{a}}$ & $19.72 \pm 2.605$ & $713.8 \pm 13.84$ \\
\hline Hazelnuts & $2.75 \pm 0.406^{\mathrm{bcd}}$ & $2.05 \pm 0.190^{\text {cdef }}$ & $13.57 \pm 0.797^{\text {cde }}$ & $55.75 \pm 1.103^{b}$ & $25.78 \pm 1.478$ & $659.6 \pm 6.70$ \\
\hline R almonds & $2.36 \pm 0.431^{\mathrm{abc}}$ & $2.87 \pm 0.071^{\mathrm{bcd}}$ & $17.10 \pm 2.018^{\mathrm{abc}}$ & $53.58 \pm 1.412^{\mathrm{bc}}$ & $24.09 \pm 2982$ & $647.0 \pm 8.51$ \\
\hline SR almonds & $2.21 \pm 0.377^{\mathrm{abc}}$ & $4.02 \pm 0.936^{\mathrm{ab}}$ & $18.39 \pm 2.563^{\mathrm{ab}}$ & $52.70 \pm 2.365^{\mathrm{bcd}}$ & $22.68 \pm 3.939$ & $638.6 \pm 14.66$ \\
\hline Brazil nuts & $2.95 \pm 0.714^{\mathrm{ab}}$ & $3.06 \pm 0.206^{\mathrm{bc}}$ & $15.27 \pm 0.159^{\mathrm{bcd}}$ & $65.21 \pm 0.656^{\mathrm{a}}$ & $13.50 \pm 0.163$ & $702.0 \pm 6.21$ \\
\hline$R$ cashew nuts & $3.85 \pm 0.454^{\mathrm{a}}$ & $2.45 \pm 0.183^{\text {cdef }}$ & $19.10 \pm 0.893^{\mathrm{ab}}$ & $42.98 \pm 1.449^{\mathrm{e}}$ & $31.61 \pm 1.541$ & $589.7 \pm 7.47$ \\
\hline SR cashew nuts & $2.74 \pm 0.262^{\mathrm{abc}}$ & $2.56 \pm 0.105^{\mathrm{cde}}$ & $18.05 \pm 0.681^{\mathrm{ab}}$ & $44.73 \pm 1.362^{\mathrm{e}}$ & $31.91 \pm 1.692$ & $602.5 \pm 7.37$ \\
\hline Pecan nuts & $3.08 \pm 0.894^{\mathrm{b}}$ & $1.25 \pm 0.085^{\mathrm{f}}$ & $9.13 \pm 0.361^{\mathrm{f}}$ & $68.81 \pm 0.768^{\mathrm{a}}$ & $17.74 \pm 1.620$ & $726.8 \pm 4.58$ \\
\hline Macadamia nuts & $1.79 \pm 0.453^{\mathrm{bc}}$ & $1.57 \pm 0.377^{\mathrm{ef}}$ & $10.40 \pm 1.822^{\mathrm{ef}}$ & $71.76 \pm 7.169^{\mathrm{a}}$ & $19.09 \pm 2.031$ & $763.8 \pm 70.25$ \\
\hline
\end{tabular}

Results given as means \pm standard deviation of triplicate analysis of three different brands of seeds in three different lots of each brand $(n=27)$, except raw pistachio $(n=9)$. Different letters in the same column indicate a significant difference by Tukey's test at $5 \%$ level of confidence. $* \mathrm{R}=$ raw, $\mathrm{SR}-$ salted roasted or toasted salted. ** Total Carbohydrates were calculated by difference: $100-(\%$ moisture $+\%$ ashes $+\%$ crude protein $+\%$ total lipids) [14].***Caloric value (kcal) of the sample was calculated by the sum of the percentages of crude protein and total carbohydrates multiplied by factor $4\left(\mathrm{Cal.g}^{-1}\right)$ added to the total lipid content multiplied by factor 9 $\left(\right.$ Cal.g $\left.^{-1}\right)$ (Holands, 1994).

SR cashew nuts, with 42.98 and $44.73 \%$, respectively. These values were statistically equal and equal to those of the R pistachio and SR pistachio samples.

The contents of carbohydrates were the lowest in Brazil nuts (13.50\%), pecan nuts (17.74\%), macadamia nuts $(19.09 \%)$, and European nuts $(19.72 \%)$. Cashew nuts had the greatest carbohydrate content (ca. 32\%), while the other seeds had between 22 and $27 \%$.

The calculated energy values showed that all the seeds were very caloric, as expected, due to their high lipid contents. The energy values of pistachio and cashew nuts were ca. $600 \mathrm{kcal} / 100 \mathrm{~g}$ and $760 \mathrm{kcal} / 100 \mathrm{~g}$ for macadamia nuts, the samples which had the lowest and the highest lipid contents, respectively. Therefore, the ingestion of cashew nuts is advisable when one wants the lowest energy content (lowest lipid content) and the greatest carbohydrate and crude protein contents.

No difference was observed in the proximal composition between raw and salted roasted cashew nuts.

Tables 2 and 3 give the contents of the major FA and the summation values of SFA, PUFA, and MUFA in g.100 $\mathrm{g}^{-1}$ and the PUFA/SFA and $\mathrm{n}-6 / \mathrm{n}-3$ ratios of the seeds analyzed calculated from the averages of the brands of the same seed for comparison with the results of the different samples. 
Table 2. Mean values of FA (g. $100 \mathrm{~g}^{-1}$ of sample) found in the seed brands analyzed

\begin{tabular}{|c|c|c|c|c|c|c|c|c|}
\hline Sample & $16: 0$ & $16: 1 \mathrm{n}-7$ & $18: 0$ & $18: 1 n-9$ & $18: 2 n-6$ & $18: 3 n-3$ & $20: 0$ & $20: 1 n-9$ \\
\hline SR pistachio* & $5.04 \pm 0.479^{\mathrm{b}}$ & $0.44 \pm 0.009^{\mathrm{a}}$ & $0.47 \pm 0.105^{\mathrm{f}}$ & $21.78 \pm 2.125^{\text {bcd }}$ & $10.92 \pm 0.165^{\mathrm{cd}}$ & $\mathrm{nd}^{* *}$ & $0.15 \pm 0.015^{\mathrm{a}}$ & $0.13 \pm 0.031^{\mathrm{bc}}$ \\
\hline R pistachio* & $4.23 \pm 0.252^{\mathrm{b}}$ & $0.58 \pm 0.022^{\mathrm{a}}$ & $0.39 \pm 0.027^{\mathrm{f}}$ & $22.70 \pm 0.324^{\text {cde }}$ & $12.85 \pm 0.162^{\mathrm{cd}}$ & nd & $0.18 \pm 0.009^{\mathrm{a}}$ & $0.19 \pm 0.009^{\mathrm{c}}$ \\
\hline Hazelnuts & $2.74 \pm 0.358^{\mathrm{c}}$ & $0.13 \pm 0.108^{\mathrm{a}}$ & $1.06 \pm 0.139^{\mathrm{ef}}$ & $39.85 \pm 0.739^{\mathrm{a}}$ & $4.68 \pm 1.254^{\mathrm{ef}}$ & $0.04 \pm 0.003^{\mathrm{b}}$ & $0.06 \pm 0.007^{\mathrm{a}}$ & $0.07 \pm 0.007^{\mathrm{c}}$ \\
\hline European nuts & $3.33 \pm 0.152^{\mathrm{c}}$ & $0.04 \pm 0.003^{\mathrm{a}}$ & $1.21 \pm 0.200^{\mathrm{def}}$ & $9.90 \pm 0.906^{\mathrm{f}}$ & $33.03 \pm 0.720^{\mathrm{a}}$ & $8.31 \pm 1.173^{\mathrm{c}}$ & $0.05 \pm 0.010^{\mathrm{a}}$ & $0.09 \pm 0.004^{\mathrm{c}}$ \\
\hline$R$ almonds & $3.52 \pm 0.716^{\mathrm{c}}$ & $0.19 \pm 0.007^{\mathrm{a}}$ & $0.51 \pm 0.013^{\text {ef }}$ & $27.85 \pm 1.871^{\mathrm{b}}$ & $14.28 \pm 1.029^{\mathrm{c}}$ & $0.01 \pm 0.001^{\mathrm{a}}$ & $0.02 \pm 0.001^{\mathrm{a}}$ & $0.03 \pm 0.005^{\mathrm{c}}$ \\
\hline SR al & $2.88 \pm 0.065^{\mathrm{c}}$ & $0.17 \pm 0.040^{\mathrm{a}}$ & $0.47 \pm 0.076^{\mathrm{f}}$ & $25.25 \pm 2.191^{\mathrm{bc}}$ & $12.59 \pm 2.326^{\mathrm{c}}$ & $0.01 \pm 0.000 \mathrm{a}$ & $0.02 \pm 0.003^{\mathrm{a}}$ & $0.08 \pm 0.086^{\mathrm{c}}$ \\
\hline R cashew nuts & $3.18 \pm 0.096^{\mathrm{c}}$ & $0.10 \pm 0.012^{\mathrm{a}}$ & $2.82 \pm 0.260^{\mathrm{bc}}$ & $24.47 \pm 0.883^{\text {bcd }}$ & $6.63 \pm 0.480^{\mathrm{de}}$ & $0.08 \pm 0.033^{\mathrm{a}}$ & $0.16 \pm 0.021^{\mathrm{a}}$ & $0.06 \pm 0.007^{\mathrm{c}}$ \\
\hline hew nuts & $3.33 \pm 0.396^{\mathrm{c}}$ & $0.10 \pm 0.026^{\mathrm{a}}$ & $3.13 \pm 0.529^{\mathrm{b}}$ & $24.10 \pm 1.335^{\mathrm{bcd}}$ & $7.28 \pm 0.297^{\mathrm{de}}$ & $0.10 \pm 0.011^{\mathrm{a}}$ & $0.20 \pm 0.025^{\mathrm{a}}$ & $0.06 \pm 0.009^{c}$ \\
\hline Brazil nuts & $8.36 \pm 0.543^{\mathrm{a}}$ & $0.16 \pm 0.018^{\mathrm{a}}$ & $4.85 \pm 0.633^{\mathrm{a}}$ & $17.98 \pm 1.523^{\mathrm{de}}$ & $22.57 \pm 3.255^{\mathrm{b}}$ & $0.06 \pm 0.043^{\mathrm{a}}$ & $0.12 \pm 0.026^{\mathrm{a}}$ & $0.02 \pm 0.003^{\mathrm{c}}$ \\
\hline Pec & $3.23 \pm 0.082^{\mathrm{c}}$ & $0.03 \pm 0.007^{\mathrm{a}}$ & $1.30 \pm 0.109^{\mathrm{de}}$ & $44.09 \pm 5.392^{\mathrm{a}}$ & $10.27 \pm 3.684^{\mathrm{cd}}$ & $0.45 \pm 0.053^{\mathrm{a}}$ & $0.04 \pm 0.010^{\mathrm{a}}$ & $0.09 \pm 0.016^{\mathrm{c}}$ \\
\hline Macadamia nuts & $5.05 \pm 0.541^{\mathrm{b}}$ & $11.19 \pm 2.197^{b}$ & $2.01 \pm 0.237^{\mathrm{cd}}$ & $39.17 \pm 4.754^{\mathrm{a}}$ & $1.06 \pm 0.182^{\mathrm{f}}$ & $0.10 \pm 0.020^{\mathrm{a}}$ & $1.48 \pm 0.237^{\mathrm{b}}$ & $1.46 \pm 0.145^{\mathrm{a}}$ \\
\hline
\end{tabular}

Results given as means \pm standard deviation of triplicate analysis of three different brands of seeds in three different lots of each brand $(n=27)$. Different letters in the same column indicate a significant difference by Tukey's test at $5 \%$ level of confidence. ${ }^{*} \mathrm{R}=$ raw, $\mathrm{SR}-$ salted roasted or toasted salted, ${ }^{* *}$ nd $=$ not detected.

Table 3. Mean values of SFA, PUFA, MUFA (g.100 g $\mathrm{g}^{-1}$ of sample) in the seed brands analyzed

\begin{tabular}{llllll}
\hline Sample & SFA & MUFA & PUFA & PUFA/SFA & n-6/n-3 \\
\hline SR pistachio* $^{*}$ & $5.67 \pm 0.506^{\text {cd }}$ & $22.36 \pm 2.151^{\text {bc }}$ & $10.92 \pm 0.165^{\mathrm{c}}$ & $1.94 \pm 0.167^{\mathrm{c}}$ & nd** \\
R pistachio* $^{*}$ & $4.80 \pm 0.274^{\mathrm{c}}$ & $23.47 \pm 0.342^{\mathrm{bc}}$ & $12.85 \pm 0.162^{\mathrm{c}}$ & $2.69 \pm 0.159$ & $\mathrm{nd}$ \\
Hazelnuts & $3.85 \pm 0.219^{\mathrm{g}}$ & $40.06 \pm 0.723^{\mathrm{f}}$ & $4.72 \pm 1.256^{\mathrm{e}}$ & $1.22 \pm 0.260^{\text {cd }}$ & $117.00 \pm 23.555^{\text {cd }}$ \\
European nuts & $4.59 \pm 0.358^{\mathrm{de}}$ & $10.02 \pm 0.906^{\mathrm{e}}$ & $41.34 \pm 1.383^{\mathrm{a}}$ & $9.05 \pm 0.780^{\mathrm{a}}$ & $3.97 \pm 0.532^{\mathrm{d}}$ \\
R almonds & $4.04 \pm 0.729^{\mathrm{ef}}$ & $28.07 \pm 1.859^{\mathrm{b}}$ & $14.29 \pm 1.028^{\mathrm{c}}$ & $3.62 \pm 0.733^{\mathrm{b}}$ & $1428.00 \pm 291.776^{\mathrm{a}}$ \\
SR almonds & $3.39 \pm 0.138^{\mathrm{f}}$ & $25.19 \pm 1.839^{\mathrm{bc}}$ & $13.15 \pm 2.651^{\mathrm{c}}$ & $3.86 \pm 0.638^{\mathrm{b}}$ & $1259.00 \pm 259.031^{\mathrm{b}}$ \\
R cashew nuts & $6.16 \pm 0.176^{\mathrm{c}}$ & $24.63 \pm 0.887^{\mathrm{bc}}$ & $6.71 \pm 0.483^{\mathrm{d}}$ & $1.09 \pm 0.111^{\text {cd }}$ & $82.88 \pm 33.923^{\text {cd }}$ \\
SR cashew nuts & $6.66 \pm 0.175^{\mathrm{c}}$ & $24.26 \pm 1.301^{\mathrm{bc}}$ & $7.38 \pm 0.307^{\mathrm{d}}$ & $1.11 \pm 0.068^{\mathrm{cd}}$ & $72.80 \pm 4.868^{\mathrm{d}}$ \\
Brazil nuts & $13.34 \pm 0.211^{\mathrm{a}}$ & $18.16 \pm 1.507^{\mathrm{cd}}$ & $22.62 \pm 3.292^{\mathrm{b}}$ & $1.70 \pm 0.276^{\mathrm{c}}$ & $376.17 \pm 236.502^{\mathrm{c}}$ \\
Pecan nuts & $4.56 \pm 0.043^{\mathrm{def}}$ & $44.21 \pm 5.391^{\text {af }}$ & $10.73 \pm 3.737^{\mathrm{cd}}$ & $2.36 \pm 0.837^{\mathrm{bc}}$ & $22.82 \pm 5.821^{\mathrm{d}}$ \\
Macadamia nuts & $9.08 \pm 0.909^{\mathrm{b}}$ & $51.83 \pm 5.701^{\mathrm{a}}$ & $1.15 \pm 0.202^{\mathrm{f}}$ & $0.13 \pm 0.024^{\mathrm{d}}$ & $10.60 \pm 0.742^{\mathrm{d}}$
\end{tabular}

Results given as means \pm standard deviation of triplicate analysis of three different brands of seeds in three different lots of each brand $(\mathrm{n}=27)$. Different letters in the same column indicate a significant difference by Tukey's test at $5 \%$ level of confidence. $* \mathrm{R}=$ raw, $\mathrm{SR}-$ salted roasted or toasted salted, $* *$ nd=notdetected.

In addition to the FA investigated, small amounts of FA 22:0 and 24:0 were found in macadamia nuts. The contents of $22: 0$ in brands $A, B$, and $C$ were $0.49 \pm 0.017^{\mathrm{a}}, 0.44 \pm 0.023^{\mathrm{ab}}$ and $0.43 \pm 0.020^{\mathrm{b}} \mathrm{g} .100 \mathrm{~g}^{-1}$ of a sample of macadamia nuts. The contents of $24: 0$ in brands $A, B$, and $\mathrm{C}$ were $0.17 \pm 0.014^{\mathrm{a}}, 0.13 \pm 0.004^{\mathrm{b}}$ and $0.15 \pm 0.013^{\mathrm{ab}}$ g. $100 \mathrm{~g}^{-1}$ of a sample of macadamia nuts.

SR cashew nuts presented trans FA, possibly formed during roasting. The trans FA contents of brands A, B, and $\mathrm{C}$ were $0.06 \pm 0.001^{\mathrm{b}}, 0.07 \pm 0.003^{\mathrm{b}}$ and $0.66 \pm 0.025^{\mathrm{a}} \mathrm{g} .100 \mathrm{~g}^{-1}$ of sample. The crispness, aroma, and flavor of roasted cashew nut are in fact developed by frying. Crispness is obtained by immersing the nuts in hydrogenated vegetable fat (trans fat) at $135^{\circ} \mathrm{C}$ for $1-2 \mathrm{~min}$. In these conditions, to obtain crispness, valuable nutritional properties are lost and a toxic load is added: Trans fat and by-products of its thermal degradation. There were no trans fatty acids in other oleaginous fruits because only toasted cashew nuts were fried in hydrogenated fat. The trans FA content of SR cashew nuts of brands A and B were statistically equal $\left(0.06\right.$ and $0.07 \mathrm{~g} .100 \mathrm{~g} \mathrm{~g}^{-1}$ of sample) and much lower than those of brand C (0.66 g.100 g of sample), which was statistically different. The World Health Organization (WHO, 1995) recommends the ingestion of not more than $1 \%$ of trans fat in the diet calories. According to WHO (1995), each gram of fat corresponds to 9 calories; thus, an adult that consumes 
2,000 calories a day should not consume more than $2 \mathrm{~g}$ of trans fats. Therefore, if a person consumes $100 \mathrm{~g}$ of cashew nuts of any of the studied brands in a day, the intake of trans fats will still be within the safe levels.

The FA values varied among some samples and no significant difference in any FA was found between the raw and salted roasted seeds studied. The FA found in greater amounts were 18:1n-9 and 18:2n-6, with significant differences among all samples.

$\mathrm{R}$ almonds, SR almonds, R cashew nuts, SR cashew nuts, and SR pistachio had 27.85; 25.25; 24.47; 24.10 and $21.78 \mathrm{~g} .100 \mathrm{~g}^{-1}$ of sample of FA $18: 1 \mathrm{n}-9$, respectively, values which were statistically equal. R pistachio had $22.70 \mathrm{~g} .100 \mathrm{~g}^{-1}$ of sample of $18: 1 \mathrm{n}-9$, which was statistically equal for SR pistachio, SR almonds, R cashew nuts, SR cashew nuts and Brazil nuts. The content of $18: 1 \mathrm{n}-9$ in the lipid fraction ranged from 50 to $60 \%$.

In contrast, FA 18:2n-6 was found in larger amounts in European nuts (33.03 g. $100 \mathrm{~g} \mathrm{~g}^{-1}$ of sample and $52 \%$ of the lipid fraction), values statistically different from those of the other samples. The second largest amount was found in Brazil nuts (22.57 g.100 g $\mathrm{g}^{-1}$ of sample), responsible for about $40 \%$ of the total lipids and a significant difference in all seeds.

Samples of R almonds, R pistachio, SR almonds, SR pistachio, and pecan nuts presented amounts of FA 18:2n-6 of $14.28,12.85,12.59,10.92$ and $10.27 \mathrm{~g} .100 \mathrm{~g}^{-1}$ of sample, respectively, with no significant difference. Pecan nuts had $15 \%$ of $18: 2 \mathrm{n}-6$ in total lipids, and the other seeds had about $25 \%$.

The SFA found in greater amounts were 16:0 and 18:0, ranging from 0.4 and 8.4 g.100 g $\mathrm{g}^{-1}$ of sample. FA 16:0 in hazelnuts, European nuts, R almonds, SR almonds, R cashew nuts, SR cashew nuts, and pecan nuts were statistically equal with values between 2.7 and $3.5 \mathrm{~g} .100 \mathrm{~g}^{-1}$ of sample, which corresponded to 4 and $7 \%$ of the lipid fraction.

Finally, Brazil nuts had greater and statistically different values of $16: 0\left(8.36 \mathrm{~g} .100 \mathrm{~g}^{-1}\right.$ of sample, equal to $13 \%$ of the total lipids).

Greater contents of FA 18:0, were also found in Brazil nuts (4.85 g.100 $\mathrm{g}^{-1}$ of sample) with significant differences from the other samples. SR pistachio, R pistachio, hazelnuts, European nuts, R almonds, and SR almonds had statistically equal amounts of $18: 0$ between 0.39 and $18: 0 \mathrm{~g} .100 \mathrm{~g} \mathrm{~g}^{-1}$ of sample.

Additionally, statistically equal amounts of FA 18:0 of 2.82 and 3.13 g.100 g $\mathrm{g}^{-1}$ of sample were found in R and SR cashew nuts, respectively. Pecan and macadamia nuts had 1.30 and $2.01 \mathrm{~g} .100 \mathrm{~g}^{-1}$ of sample, values which were also statistically equal. The amounts of 18:0, in European nuts, R and SR almonds; pecan nuts, European nuts, pecan nuts and macadamia nuts; $\mathrm{R}$ cashew nuts and macadamia nuts were also statistically equal.

Another SFA found in the samples was 20:0, but its values were lower than 0.3 g. $100 \mathrm{~g}^{-1}$ of sample, except in macadamia nuts, which had $1.48 \mathrm{~g} .100 \mathrm{~g}^{-1}$ of sample. The values of all samples, except macadamia nuts, were equal.

Essential FA 18:3n-3 was not found in R and SR pistachio, but was found in very small quantities (from 0.01 to $0.45 \mathrm{~g} .100 \mathrm{~g} \mathrm{~g}^{-1}$ ), with European nuts standing out with $8.31 \mathrm{~g} .100 \mathrm{~g}^{-1}$ of sample, a value statistically different from those of the other samples. Thus, $13 \%$ of the total lipids of European nuts are FA 18:3n-3. Besides European nuts, pecan nuts also had statistically different and higher values of $18: 3 \mathrm{n}-3\left(0.45 \mathrm{~g} .100 \mathrm{~g}^{-1}\right.$ of sample, $8 \%$ of the total lipids). All the other samples were statistically equal.

Table 3 gives the calculated $n-6 / n-3$ ratios of all seeds. Among the benefits of a low $n-6 / n-3$ ratio are the reduction of $70 \%$ in the mortality ratio in cardiovascular patients, the reduction of inflammation caused by rheumatoid arthritis, and the reduction of the symptoms of asthma (Martin, Almeida, Ruiz, Visentainer, Matshushita, Souza, \& Visentainer, 2006).

Additionally, the values were high for most samples, ranging from ca. 100 in cashew nuts and hazelnuts, to ca. 400 in Brazil nuts, up to ca. 1400 in almonds. Now, pecan and macadamia nuts had lower ratios, 23 and 11, respectively. However, the calculated essential FA n-6/n-3 ratio of European nuts is very low, 3.97, which makes this seed very healthy, as according to Simopoulos (2004), this ratio must be between 1:1 and 4:1. Therefore, European nuts have significant amounts of $18: 3 n-3$, with a very beneficial $n-6 / n-3$ ratio $(4: 1)$. Therefore, this is a choice for the intake of larger amounts of n-3 family FA.

The amounts of FA 16:1n-7 were low in these samples, expect in macadamia nuts, which have $11.19 \mathrm{~g} .100 \mathrm{~g} \mathrm{~g}^{-1}$ of sample, accounting for $16 \%$ of the total lipids.

Another FA found in low amounts in the seeds was 20:1n-9. The largest amount was found in macadamia nuts $\left(1.46 \mathrm{~g} \cdot 100^{-1}\right.$ of sample). The other samples had from 0.03 to $0.20 \mathrm{~g} .100 \mathrm{~g}^{-1}$ of sample. All samples were equal (p $<5 \%$ ), except macadamia nuts. 
The sum of SFA in Brazil nuts were the highest (13.34 g. $100 \mathrm{~g}^{-1}$ of sample, $23 \%$ of the total lipids), a value that was statistically different from those of the other samples. Macadamia nuts had $9.08 \mathrm{~g} .100 \mathrm{~g}^{-1}$ of sample of SFA with significant differences from other seeds. SFA represent $14 \%$ of the total lipids in pistachio samples, cashew nuts and macadamia nuts, and 7\% in hazelnuts, European nuts, almonds and pecan nuts.

The MUFA summation was the greatest in macadamia and pecan nuts, 51.83 and $44.21 \mathrm{~g} .100 \mathrm{~g}^{-1}$, respectively, with statistically equal values. However, pecan nuts were also equal to hazelnuts, $40.06 \mathrm{~g} .100 \mathrm{~g} \mathrm{~g}^{-1}$ of sample. R and SR pistachio, R and SR almonds, R and SR cashew nuts had MUFA contents ranging from 22.36 to 28.07 g. $100 \mathrm{~g}^{-1}$ of sample. The samples were statistically equal.

Brazil nuts had 18.16 g. $100 \mathrm{~g}^{-1}$ of sample of MUFA, being equal to R and SR cashew nuts, SR almonds, and R pistachio. The lowest sums were found in European nuts (10.02 g.100 g of sample).

The analysis of the results in Tables 2 and 3 shows that MUFAS (16:1n-7, 18:1n-9 and 20:1n-9) add up to 20\% (European nuts) and $81 \%$ (macadamia nuts) of the total lipids present in the samples, $18: 1 \mathrm{n}-9$ being responsible for almost all this amount. Most of the samples had over 50\% MUFA of the total lipids. These results are considered very beneficial to human health, as this class of FA is responsible for the reduction of LDL and total cholesterol, and the preferential ingestion of this type of fat is recommended.

However, it was observed that some of these oleaginous fruits have very high values of the $\mathrm{n} 6 / \mathrm{n} 3$ ratio as cashew nuts $(100)$, the Brazilian nuts $(400)$ and almonds $(\sim 1400)$, which decreases nutritional value of these foods. Therefore, those in need to reduce the LDL cholesterol levels must preferably consume macadamia nuts due to their higher MUFA contents and present a relatively low values of the n6/n3 ratio (Martin et al., 2006).

The PUFA found in the samples were 18:2n-6 and 18:3n-3, with very little amounts of the latter in almost all samples, except in European nuts. Thus, nearly all PUFA in the seeds are due to 18:2n-6. However, it is believed that consumption of 18:2 n- 6 can reduce LDL and total cholesterol, but if ingested in excess (above 10\% of total calorie intake), this fatty acid can cause reduced beneficial cholesterol, HDL. Moreover, much higher amounts of 18:2 n-6 in relation to $18: 3 \mathrm{n}-3$ results in high $\mathrm{n} 6 / \mathrm{n} 3$ ratios, causing reduced production of eicosapentaenoic acid (EPA), which contributes to the development of allergic diseases, inflammatory and cardiovascular diseases (Martin et al., 2006).

The PUFA summation did not vary significantly in SR pistachio, R pistachio, R almonds, SR almonds, and pecan nuts, with values ranging from 10.73 to $14.29 \mathrm{~g} .100 \mathrm{~g}^{-2}$ of sample. However, the contents in European nuts (41.34 g. $100 \mathrm{~g} \mathrm{~g}^{-1}$ of sample) and Brazil nuts (41.34 g.100 g $\mathrm{g}^{-1}$ of sample) were higher, being significantly different from each other and from the other samples. R and SR cashew nuts were statistically equal, with 6.71 and 7.38 g. $100 \mathrm{~g}^{-1}$.

The summation of PUFA was lower in hazelnuts (4.72 g.100 g $\mathrm{g}^{-1}$ of sample) and in macadamia nuts (1.15 g.100 $\mathrm{g}^{-1}$ of sample), which were significantly different from each other and the values of the other samples.

Table 3 also shows the PUFA/SFA ratio, which gives information on the quality of the FA present in food. Values lower than 0.45 are considered little healthy, principally concerning cardiovascular diseases, as recommended by the Department of Health and Social Security (DHSS, 1994) of England.

Thus, a greater PUFA/SFA ratio of 9 was found for European nuts. Almonds had a ratio higher than 3.6. Values between 1.9 and 2.6 were found in pistachio and pecan nuts. Ratios between 1.0 and 1.7 were obtained for hazelnuts, cashew nuts, and Brazil nuts. However, macadamia nuts had a ratio of 0.13 , much lower than the ideal limit of 0.45 . However, this figure does not mean that they are unhealthy, as more than $80 \%$ of their lipid content is MUFA, which, as previously mentioned, are very beneficial to health.

\section{Conclusions}

As expected, all seeds had low moisture and high total lipid contents. Furthermore, all samples had significant amounts of crude protein, which is nutritionally valuable.

As to FA, among seven and nine FA were identified and quantified in the different samples. FA 18:1n-9 and 18:2n-6 had the greatest contents. Essential FA 18:3n-3 was also found, except in pistachio. However, European nuts had significant amounts, with an $n-6 / n-3$ ratio of 3, beneficial to health (4:1). Additionally, SR cashew nuts also had trans FA, which may have been formed during the roasting process.

The present results indicate that the oleaginous seeds consumed by the Brazilian population have desirable nutritional characteristics, whereas these fruits have a value of SFA and PUFA much higher than SFA, and food are classified as "zero trans". However, macadamia nuts and europe nuts stood out among the other fruits for 
their nutritional characteristics: macadamia nuts showed high levels of MUFA and one of the lowest ratios n6/n3, and walnuts european $\mathrm{n} 6 / \mathrm{n} 3$ values presented within recommended.

\section{Acknowledgements}

The authors are grateful to CAPEs, CNPq and Fundação Araucária for the financial support.

\section{References}

Alexiadou, K., \& Katsilambros, N. (2011). Nuts: Anti-atherogenic food? European Journal of Internal Medicine, 22, 141-146. http://dx.doi.org/10.1016/j.ejim.2010.11.008

Bligh, E. G., \& Dyer, W. J. (1959). A rapid method of total lipid extraction and purification. Canadian Journal of Biochemistry Physiology, 37, 991-917.

Cunniff, P. A. (1998). Official methods of Analysis of AOAC international (6th ed.). Arlington: AOAC, CD-Rom.

Department of Health and Social Security (DHSS). (1994). Report on Health and Social Subjects. Diet and Cardiovascular Disease, HMSO, London.

Esfahlan, A. J., Jamei, R., \& Esfahlan, R. J. (2010). The importance of almond (Prunusamygdalus L.) and its by-products. Food Chemistry, 120, 349-360. http://dx.doi.org/10.1016/j.foodchem.2009.09.063

Hartman, L., \& Lago, R. C. A. (1973). Rapid preparation of fatty acid methyl esters from lipids. LaboratoryPractice, 22, 475-477.

Holands, B. (1994). "Southgate. MacCance and Winddoeson's". In A. A. Welch, I. D. Unwin, D. H. Buss, \& A. A. Paul (Eds.), The Composition of Foods (5th ed.). The Royal Society of Chemistry and Ministry of Agriculture, Fisheries and Food. Cambridge, UK. http://dx.doi.org/10.1590/S1415-52732006000600011

Instituto Adolfo Lutz. (2005). Normas analíticas do Instituto Adolfo Lutz. IV-Métodos químicos e físicos para análise de alimentos. São Paulo (5th ed.). Secretária de Estado da Saúde, Coordenadoria dos Serviços Especializados.

Jun, Y. (2009). Brazil nuts and associated health benefits: A review. LWT - Food Science and Technology, 42, 1573-1580. http://dx.doi.org/10.1016/j.lwt.2009.05.019

Kornsteiner, M., Wagner, K. H., \& Elmadfa, I. (2006). Tocopherols and total phenolics in 10 different nut types. Food Chemistry, 98, 381-387. http://dx.doi.org/10.1016/j.foodchem.2005.05.077

Maia, E. L., \& Rodriguez-Amaya, D. B. (1993). Avaliação de um método simples e econômico para a metilação de ácidos graxos com lipídios de diversas espécies de peixes. Revista do Instituto Adolfo Lutz, 53, 27-35.

Martin, C. A., Almeida, V. V., Ruiz, M. R., Visentainer, J. E. L., Matshushita, M., Souza, N. E. \& Visentainer, J. V. (2006). Omega-3 and omega-6 polyunsaturated fatty acids: importance and occurrence in foods. Revista de Nutrição, 19(6), 761-770. http://dx.doi.org/10.1590/S1415-52732006000600011

Naozuka. J, Vieira, E. C., Nascimento, A. N., \& Oliveira, P. V. (2011). Elemental analysis of nuts and seeds by axially viewed ICP OES. Food Chemistry, 124, 1667-1672. http://dx.doi.org/10.1016/j.foodchem.2010.07.051

Ritter, M. M. C., \& Savage G. P. (2007). Solubleandinsolubleoxalate content of nuts. Journal of Food Composition and Analysis, 20, 169-174. http://dx.doi.org/10.1016/j.jfca.2006.12.001

Salas-Salvado, J., Casas-Agustench, P., \& Salas-Huetos, A. (2011). Cultural and historical aspects of Mediterranean nuts with emphasis on their attributed healthy and nutritional properties. Nutrition Metabolism And Cardiovascular Diseases, 21, S1-S6. http://dx.doi.org/10.1016/j.numecd.2010.10.013

Sathe, S. K. (1994). Solubilization and electrophoretic characterization of cashew nut (Anacardiumoccidentale) proteins. Food Chemistry, 51, 319-324. http://dx.doi.org/10.1016/0308-8146(94)90033-7

Simopoulos, A. C. (2004). Omega-6/omega-3 essential fatty acid ratio and chronic diseases. Food Reviews International, 20(1), 77-90.

Statistica. (2005). Statistica 5.0 Software. StaSoft, Tucksa.

Visentainer, J. V. (2006). Ácidos graxos em óleos e gorduras: Identificação e quantificação. In: Franco MRB. São Paulo. Varela.

World Health Organization (WHO). (1995). Joint Consultation: fats and oils in human nutrition. Nutrition Reviews, 53(7), 202-205. 
Yada, S., Lapsley, K., \& Huang, G. (2011). A review of composition studies of cultivated almonds: Macronutrients and micronutrients. Journal of Food Composition and Analysis, 24, 469-480. http://dx.doi.org/10.1016/j.jfca.2011.01.007

Yang, J., Liu, R. H., \& Halim, L. (2009). Antioxidant and antiproliferative activities of common edible nut seeds. LWT - Food Science and Technology, 42, 1-8. http://dx.doi.org/10.1016/j.lwt.2008.07.007 